\title{
Residues of melamine and cyanuric acid in milk and tissues of dairy cows fed different doses of melamine
}

\author{
P. Sun, ${ }^{*} \dagger$ J. Q. Wang, ${ }^{* 1}$ J. S. Shen, ${ }^{\star}$ and H. Y. Wei ${ }^{\star} \dagger$ \\ *State Key Laboratory of Animal Nutrition, Institute of Animal Science, Chinese Academy of Agricultural Sciences, Beijing, 100193, P. R. China \\ †Ministry of Agricultural Milk and Dairy Inspection and Supervision Center (Beijing), Beijing, 100193, P. R. China
}

\begin{abstract}
Melamine (1,3,5-triazine-2,4,6-triamine) may be degraded into cyanuric acid and some other compounds by rumen microorganisms. This study was conducted to assess the transfer of melamine and cyanuric acid in to milk and tissues by dairy cows fed different doses of melamine. Forty mid-lactation dairy cows $(157 \pm 43 \mathrm{~d}$ in milk, $20.8 \pm 1.4 \mathrm{~kg}$ of milk/d) were divided into 4 groups ( $\mathrm{n}=10 /$ group) using a completely randomized design. The groups were fed the following amounts of melamine (purity $\geq 99.5 \%$ ) at 0 (control), 300 [treatment (Trt) 1], 500 (Trt 2), and 1,000 (Trt 3) mg/d per cow, respectively. The trial lasted for $18 \mathrm{~d}$ (12-d feeding period, followed by a 6 -d clearance period). Milk samples were collected from the 4 groups on d 1, 2, 3, $4,8,12,13,14,15$, and 18 , and analyzed for melamine and cyanuric acid. On d 13, 3 cows from Trt 2 and Trt 3 were randomly selected and slaughtered; tissue samples including kidney, liver, mammary, bladder, gluteus medius, and longissimus dorsi were collected for melamine and cyanuric acid analyses. Milk and tissue samples were analyzed for melamine and cyanuric acid using a simultaneous liquid chromatography tandem mass spectrometry procedure. Neither melamine nor cyanuric acid was detected in concentrated feed that was being fed to the cows. In melamine-treated groups, milk melamine concentration increased quickly and reached a stable level by d 4 and was at similar levels on d 8 and 12 after the first administration of melamine. Milk melamine levels in treated groups were $0.18,0.27$, and $0.50 \mathrm{mg} / \mathrm{L}$ for Trt 1, Trt 2, and Trt 3, respectively, and were highly correlated $\left(\mathrm{R}^{2}=0.91\right)$ with melamine dosing levels. No cyanuric acid was detected in any of the milk collected from the various groups. Melamine residue levels in tissues of Trt 3 were about 2-fold higher than that in Trt 2, with the highest concentration being found in kidney. No differences in cyanuric acid levels in tissues were found between Trt
\end{abstract}

Received November 18, 2010.

Accepted March 21, 2011.

${ }^{1}$ Corresponding author: jqwangcaas@gmail.com
3 and Trt 2. Liver, kidney, and bladder tissues were found to contain the highest cyanuric acid levels. This study shows a relationship between dietary melamine levels and cyanuric acid levels found in tissues, which might be the result of melamine being converted to cyanuric acid by microorganisms in the rumen.

Key words: melamine, cyanuric acid, dairy cow, milk and tissue

\section{INTRODUCTION}

Melamine (1,3,5-triazine-2,4,6-triamine) is a relatively stable substance that is mainly used for the production of melamine resins and plastics (Subrayan and Rasmussen, 1995; Weil and Choudhary, 1995). Although melamine is believed to have low oral toxicity because of its stable and insoluble properties that prevent it from being hydrolyzed in the body (Newton and Utley, 1978), excessive intake by human or animals has been shown to cause crystalluria and renal damage (Brown et al., 2007; Shen et al., 2010). The European Food Safety Authority (EFSA, 2008) recommends that melamine total daily intake (TDI) be less than 0.5 $\mathrm{mg} / \mathrm{kg}$ of BW. The US Food and Drug Administration (FDA, 2007) guidelines recommend that TDI of melamine and its analogs should be less than $0.63 \mathrm{mg} /$ $\mathrm{kg}$ of BW per day for adults and $0.063 \mathrm{mg} / \mathrm{kg}$ of BW per day for infants, respectively (FDA, 2008b). The addition of melamine to animal feeds or human foods is strictly prohibited.

Several studies have shown that melamine is not metabolized by the body and is excreted by the kidneys (Newton and Utley, 1978; Lam et al., 2009). Mast et al. (1983) reported that $90 \%$ of ingested melamine would be excreted by kidneys within 24 h. Baynes et al. (2008) demonstrated that body distribution of melamine may be limited to the body water fraction and melamine was unlikely to be bound in significant amounts to the tissues. When large quantities of melamine are ingested that exceed the excretion capability of kidney, then renal disease and even death may occur in animals (Ogasawara et al., 1995; Puschner et al., 2007; Dobson et al., 2008) and humans (Lam et al., 2009). However, 
Jutzi et al. (1982) and Shelton et al. (1997) showed that melamine could be metabolized by Pseudomonas spp. and Klebsiella terragena to form cyanuric acid in vitro. Other recent studies showed increased toxicity resulting from combined exposure of animals to melamine and cyanuric acid (Puschner et al., 2007; Reimschuessel et al., 2008), which raises a high degree of uncertainty with regard to the assessment of risk and safety in animals consuming melamine. The FDA (2008a) has applied an additional 10-fold safety factor to compensate for these uncertainties and recommends that the TDI of melamine be $<0.063 \mathrm{mg} / \mathrm{kg}$ in food and food ingredients other than infant formula.

Most previous studies have focused on monogastric animals, but melamine metabolism in dairy cows and residues in milk have not been studied. Given the complex and diverse microbial population that is present in the rumen, we hypothesize that melamine might be transformed by ruminal microbes (bacteria, fungi, and protozoa) to form cyanuric acid and other related compounds, such as ammelide and ammeline. These degradation products may find their way into milk and tissues when dairy cows consume feed tainted with melamine. Therefore, the objective of this study was to investigate the transfer of melamine and cyanuric acid (a rumen metabolite of melamine) into milk and tissues of dairy cows receiving different doses of melamine.

\section{MATERIALS AND METHODS}

\section{Experimental Design and Treatments}

The study was performed at the Beijing Cangdafu Dairy Farm (Beijing, China). Animal care and procedures were approved and conducted under established standards of the Institute of Animal Science, Chinese Academy of Agricultural Sciences, Beijing, China. Health of cows was monitored continuously before and during the experimental period.

Forty mid-lactation Holstein dairy cows $(157 \pm 43$ DIM, $20.8 \pm 1.4 \mathrm{~kg}$ of milk/d, and $2.9 \pm 0.8$ parity) were randomly assigned to 1 of 4 groups $(\mathrm{n}=10$ / group). The whole trial lasted for $18 \mathrm{~d}$, during which the first $12 \mathrm{~d}$ was the feeding period and the last $6 \mathrm{~d}$ was the clearance period. In the feeding period, cows were dosed with melamine at 0 (control), 300 [treatment (Trt) 1], $500($ Trt 2), and 1,000 (Trt 3) mg/d per cow, respectively. The melamine (purity $\geq 99.5 \%$ ) used in this trial was obtained from Beijing Chemical Reagent Company (Beijing, China). During the first 12 d (feeding period), before each morning feeding, cows were allowed to consume all the added melamine mixed with about $35 \mathrm{~g}$ of concentrate (composed of $50 \%$ soybean meal and 50\% corn powder). During the last $6 \mathrm{~d}$ of the 18-d feeding period, the melamine was removed from the diet and the cows were monitored for the 6 -d clearance period.

All cows were fed the same basal diet (Table 1) as a TMR, which was formulated to satisfy the nutrient recommendations for $25 \mathrm{~kg} / \mathrm{d}$ of milk production according to the Feeding Standards of Dairy Cattle (China $\mathrm{NY} / \mathrm{t} 34,2004)$. Ingredients and chemical composition of the basal diet are listed in Table 1 . The TMR was fed 3 times daily at 0730, 1430, and $2000 \mathrm{~h}$ in amounts to ensure approximately $5 \%$ refusals. Cows were milked 3 times daily (0930, 1530, and $2300 \mathrm{~h}$ ) and individual cow milk yields were recorded for each milking.

\section{Sampling and Analysis}

Before the trial started, melamine and cyanuric acid in the samples of feed ingredients and milk from all the cows were analyzed for determination of potential background concentration. During the experimental periods, concentrate and forage ingredient samples were collected on d 1, 5, 10, 15, and 19 of the experimental period and analyzed to determine background concentrations of melamine.

Table 1. Ingredient composition and nutrient levels of the basal diet (DM basis)

\begin{tabular}{|c|c|}
\hline Item & $\begin{array}{c}\% \text { of } \\
\text { Ration DM }\end{array}$ \\
\hline \multicolumn{2}{|l|}{ Ingredient } \\
\hline Corn silage & 28.00 \\
\hline Chinese wild rye hay & 14.00 \\
\hline Brewers grain & 7.50 \\
\hline Bean curd residue & 6.00 \\
\hline Corn & 19.00 \\
\hline Cottonseed meal & 6.50 \\
\hline Wheat bran & 3.70 \\
\hline Soybean meal & 1.75 \\
\hline Peanut meal & 2.40 \\
\hline Yeast powder & 2.75 \\
\hline Scrap tankage & 3.10 \\
\hline Corn embryo cake & 1.85 \\
\hline Salt & 0.50 \\
\hline Premix $^{1}$ & 0.50 \\
\hline Sodium bicarbonate & 0.90 \\
\hline Calcium monohydrogen phosphate & 0.40 \\
\hline Limestone & 0.75 \\
\hline Calcium carbonate precipitated light & 0.40 \\
\hline \multicolumn{2}{|l|}{ Chemical analysis $^{2}$} \\
\hline $\mathrm{NE}_{\mathrm{L}}^{3}(\mathrm{MJ} / \mathrm{kg}$ of $\mathrm{DM})$ & 6.23 \\
\hline $\mathrm{CP}$ & 15.92 \\
\hline Ether extract & 4.69 \\
\hline $\mathrm{NDF}$ & 41.30 \\
\hline $\mathrm{ADF}$ & 22.97 \\
\hline $\mathrm{Ca}$ & 0.72 \\
\hline $\mathrm{P}$ & 0.36 \\
\hline \multicolumn{2}{|c|}{$\begin{array}{l}{ }^{1} \text { Contained (per kilogram of DM) a minimum } 250,000 \mathrm{IU} \text { of vitamin } \\
\mathrm{A} ; 65,000 \mathrm{IU} \text { of vitamin D; 2,100 IU of vitamin E; Fe, } 400 \mathrm{mg} \text {; Cu, } \\
540 \mathrm{mg} \text {; Zn, 2,100 mg; Mn, } 560 \mathrm{mg} \text {; Se, } 15 \mathrm{mg} \text {; I, 35 mg; Co, } 68 \mathrm{mg} \text {. } \\
{ }^{2} \text { Analyzed value. } \\
{ }^{3} \text { Calculated value (based on China NY/t } 34.2004 \text { ). }\end{array}$} \\
\hline
\end{tabular}


Milk samples were collected at d 1, 2, 3, 4, 8, 12, 13, 14, 15, and 18 from each cow. Approximately 150 $\mathrm{mL}$ of milk collected from individual cows from the 3 daily milkings was composited in a 4:3:3 ratio (a ratio, reflecting the milk yields from the 3 milkings at 0930, $1530,2300 \mathrm{~h}$, respectively) and divided into 2 aliquots of $50 \mathrm{~mL}$ each. One aliquot was frozen and immediately stored at $-20^{\circ} \mathrm{C}$ until analyzed for melamine and cyanuric acid. The second aliquot, collected on d 4, 8 , and 12 of the feeding period, was stored at $4^{\circ} \mathrm{C}$ and analyzed within $24 \mathrm{~h}$ for determination of fat, protein, urea, lactose, casein, TS, and SNF contents using infrared analysis (Foss MilkoScan, Foss Food Technology Corp., Eden Prairie, MN).

Blood samples $(10 \mathrm{~mL})$ were taken from the tail artery using Vacutainer tubes (BD Biosciences, San Jose, CA) containing heparin anticoagulant before morning feeding on $\mathrm{d} 11$ and were centrifuged at $4^{\circ} \mathrm{C}$ and $3,000 \times g$ for $15 \mathrm{~min}$. The separated plasma was stored at $-20^{\circ} \mathrm{C}$ until analysis for $\mathrm{K}, \mathrm{Na}, \mathrm{Cl}$, total $\mathrm{CO}_{2}$, $\mathrm{Ca}$, albumin, alanine aminotransferase, BUN, glucose, cholesterol, creatinine, total bilirubin, aspartate aminotransferase, alkaline phosphatase, $\gamma$-glutamyl transferase, total protein, uric acid, and globulin anion gap. On d 13, 3 cows were randomly selected from Trt 2 and Trt 3 and slaughtered after blood collection. Tissue samples including kidney, liver, mammary, bladder, gluteus medius, and longissimus dorsi were collected and stored at $-20^{\circ} \mathrm{C}$ until analysis for melamine and cyanuric acid.

\section{Determination of Melamine and Cyanuric Acid in Diets, Plasma, Milk, and Tissues}

Feed, milk, and tissue samples were analyzed for melamine and cyanuric acid simultaneously by liquid chromatography/tandem mass spectrometry as described by Filigenzi et al. (2008) with some modifications. Melamine and cyanuric acid standards were purchased from Sigma Chemical Co. (St. Louis, MO; purity of $99 \%$ ). ${ }^{15} \mathrm{~N}_{3}$-Melamine and ${ }^{13} \mathrm{C}_{3}$-cyanuric acid were obtained from Icon Services (Summit, NJ) for use as internal standards. A melamine solution at $1.0 \mathrm{mg} /$ $\mathrm{mL}$ was used as a stock standard solution and prepared by dissolving $100 \mathrm{mg}$ of melamine in $100 \mathrm{~mL}$ of $2 \%$ formic acid solution. Then, the working solutions of melamine were prepared by further dilution ranging from 0.5 to $10 \mu \mathrm{g} / \mathrm{mL}$. Similar preparation of stock standard solution and working standard solutions was performed for cyanuric acid standards. The samples of diets were finely ground to pass through a 40-mesh sieve and then a 1-g portion was dissolved in $20 \mathrm{~mL}$ of $2 \%$ mixture solution of formate, acetonitrile, and deionized water $(70: 20: 10, \mathrm{vol} / \mathrm{vol} / \mathrm{vol})$ in a $50-\mathrm{mL}$ centrifuge tube. Then, $80 \mu \mathrm{L}$ of standard melamine solution and
$240 \mu \mathrm{L}$ of standard cyanuric acid solution were added. After vibrating on a vortex mixer for $5 \mathrm{~min}$, the mixed solution was extracted ultrasonically for $15 \mathrm{~min}$ and then vortexed for 10 min before being centrifuged at $10,000 \times g$ for $10 \mathrm{~min}$. The resultant supernatant from each sample was loaded onto a reversed-phase column (Symmetry, C18, $5 \mu \mathrm{m}, 4.6 \times 150 \mathrm{~mm}$, Waters Ireland, Dublin, Ireland) at a flow rate of $1 \mathrm{~mL} / \mathrm{min}$, and the column was washed with formic acid in water and acetonitrile, eluted with ammonium acetate in water using a gradient elution program, and dried under a stream of nitrogen at $60^{\circ} \mathrm{C}$. The dried extract was dissolved in $2 \mathrm{~mL}$ of acetonitrile solution and vortexed for $1 \mathrm{~min}$ before being filtered through a $0.45-\mu \mathrm{m}$ filter (Millipore Corp., Milford, MA). Aliquots of raw milk (2 $\mathrm{mL})$ and plasma $(0.5 \mathrm{~mL})$ were processed similarly. All melamine and cyanuric acid concentrations in tissues are expressed on a wet weight basis. The tissue samples were prepared according to previous publication (Filigenzi et al., 2008; Wu et al., 2009) and processed as described above. The detection limits for melamine and cyanuric acid were 0.05 and $0.2 \mathrm{mg} / \mathrm{kg}$ for feed samples, 0.02 and $0.05 \mathrm{mg} / \mathrm{kg}$ for milk and plasma samples, and 0.05 and $0.025 \mathrm{mg} / \mathrm{kg}$ for tissue samples, respectively.

\section{Statistical Analysis}

Milk yield, milk composition, milk melamine concentration, melamine excretion via milk, and transfer efficiency were analyzed using the MIXED procedures of SAS (version 9.0, SAS Institute Inc., Cary, NC). Because no melamine was detected in the control group, no statistical analyses were done on milk melamine of the control group. Fixed effects in the model included treatment, day, and treatment $\times$ day interaction. The variance for cow was used as random effect. The day of collection was a repeated measure (compound symmetry covariance structure). Differences among treatments were analyzed using Tukey's multiple range test. $P$-values $\leq 0.05$ were considered statistically significant.

Transfer efficiency of ingested melamine to milk (Trt 1, Trt 2, and Trt 3) was calculated separately for each cow using the ratio between the mean daily amount of melamine ingested and that excreted in milk on d 4, 8 , and 12 of the feeding period. Regression analysis was performed for average milk melamine concentration, and melamine intake was determined for individual cows.

\section{RESULTS AND DISCUSSION}

\section{Melamine and Cyanuric Acid in Cow TMR}

No melamine or cyanuric acid was detected in the forage or concentrate feed that the dairy cows consumed in the current study. 
Table 2. Milk yield and composition of experimental groups receiving different doses of melamine (samples were collected at d 4, 8, and 12)

\begin{tabular}{|c|c|c|c|c|c|c|c|c|}
\hline Item & \multicolumn{4}{|c|}{ Treatment $(\text { Trt })^{1}$} & SEM & \multicolumn{3}{|c|}{$P$-value } \\
\hline Milk yield (kg/d) & 21.76 & 22.22 & 21.10 & 23.24 & 0.66 & 0.13 & 0.13 & 0.73 \\
\hline Protein $(\mathrm{kg} / \mathrm{d})$ & 0.73 & 0.74 & 0.76 & 0.77 & 0.02 & 0.67 & 0.15 & 0.70 \\
\hline Fat $(\%)$ & 4.07 & 3.92 & 4.36 & 3.94 & 0.15 & 0.18 & 0.10 & 0.51 \\
\hline Fat $(\mathrm{kg} / \mathrm{d})$ & 0.89 & 0.87 & 0.91 & 0.91 & 0.04 & 0.83 & 0.04 & 0.77 \\
\hline Urea (g/d) & 5.88 & 6.38 & 5.99 & 6.83 & 0.35 & 0.24 & $<0.01$ & 0.38 \\
\hline TS $(\%)$ & 13.12 & 12.96 & 13.60 & 12.99 & 0.20 & 0.11 & 0.19 & 0.55 \\
\hline TS (kg/d) & 2.86 & 2.88 & 2.85 & 3.02 & 0.09 & 0.54 & 0.06 & 0.77 \\
\hline $\operatorname{SNF}(\%)$ & 9.07 & 9.04 & 9.24 & 9.04 & 0.08 & 0.24 & 0.63 & 0.66 \\
\hline $\mathrm{SNF}(\mathrm{kg} / \mathrm{d})$ & 1.97 & 2.01 & 1.94 & 2.10 & 0.06 & 0.30 & 0.15 & 0.63 \\
\hline
\end{tabular}

${ }^{1}$ Cows were administered melamine at $0,300,500$, and $1,000 \mathrm{mg} / \mathrm{d}$ per cow for control, Trt 1, Trt 2, and Trt 3, respectively.

\section{Milk Production and Composition}

Milk yield and composition for treatment groups are summarized in Table 2. Neither milk yield nor milk composition was influenced by the supplementation of low levels of melamine in the diet. Similar results were obtained by Cruywagen et al. (2009) and in our previous studies (Shen et al., 2010).

\section{Plasma Parameters}

Effects of different doses of melamine on the plasma parameters of dairy cows are shown in Table 3 . Concentrations of BUN, uric acid, and creatinine are important indicators that reflect the kidney function, whereas aspartate aminotransferase, alkaline phosphatase, $\gamma$-glutamyl transferase, total bilirubin, and alanine aminotransferase are indicators of liver function. As shown in Table 3, no difference was observed in plasma parameters of dairy cows receiving different doses of melamine. Clark (1966) found that the blood urea and creatinine levels in sheep rose sharply after consumed 10 $\mathrm{g}$ of melamine per day. However, Puschner et al. (2007) demonstrated that oral administration of melamine at a dose of $10 \mathrm{~g} / \mathrm{kg}$ of diet per day did not increase blood urea or creatinine concentrations in cats. Other researchers found that when melamine and cyanuric acid were fed together, the blood urea and creatinine concentrations in cats were significantly increased and melamine crystals were found in the kidney (Puschner et al., 2007; Dobson et al., 2008). Consistent with those publications, results in the present study showed that supplementation with less than $1,000 \mathrm{mg} / \mathrm{d}$ of melamine did not influence the cow's health.

\section{Melamine and Cyanuric Acid Residues in Milk}

Neither melamine nor cyanuric acid was detected in pretrial milk samples. During the experimental period, no melamine was detected in milk from the control group. The variation of milk melamine concentration in Trt 1, Trt 2, and Trt 3 is presented in Figure 1. On the first day of the feeding period, melamine could be detected in the milk from all 3 melamine-supplemented groups. The milk melamine levels increased during the next $3 \mathrm{~d}$ of the trial period and then fluctuated only slightly over the remaining $10 \mathrm{~d}$ of the feeding period. Battaglia et al. (2010) found that maximal melamine concentrations occurred between 6 and $18 \mathrm{~h}$ after the dairy cows consumed the melamine-supplemented diet in a single dose. The continuous ingestion of melamine might cause a different phase of emergence of maximal milk melamine concentrations in our study. After melamine administration was terminated, milk melamine levels decreased rapidly, and little melamine $(<0.05 \mathrm{mg} / \mathrm{kg})$ was detected in milk from any of the treatment groups $3 \mathrm{~d}$ after melamine dosing was terminated. No melamine could be detected (detection limit was $0.02 \mathrm{mg} / \mathrm{kg}$ ) in milk from any of the treatment groups $7 \mathrm{~d}$ after the termination of melamine administration. Similar results were observed in our previous study (Shen et al., 2010) and those of others (Battaglia et al., 2010).

In the present study, the mean milk melamine concentration $(0.18,0.27$, and $0.51 \mathrm{mg} / \mathrm{L}$ for Trt 1 , Trt 2 and Trt 3, respectively) was significantly related to melamine dosing level $(P<0.01)$. However, the transfer efficiency $(1.09,1.02$, and $1.12 \%$ for Trt 1 , Trt 2 , and Trt 3, respectively) was found not to be associated with the melamine intake (Table 3 ). Our previous study suggested that the transfer efficiency of melamine from feed to milk was positively correlated with milk yield; that is, as milk yield increased, the transfer rate also increased (Shen et al., 2010). Therefore, different milk yields of the cows might be the reason why the transfer efficiency obtained in our study was much lower than 
Table 3. Least squares means of plasma parameters of the experimental groups that received different doses of melamine (samples were collected before morning feeding on $\mathrm{d} 12$ )

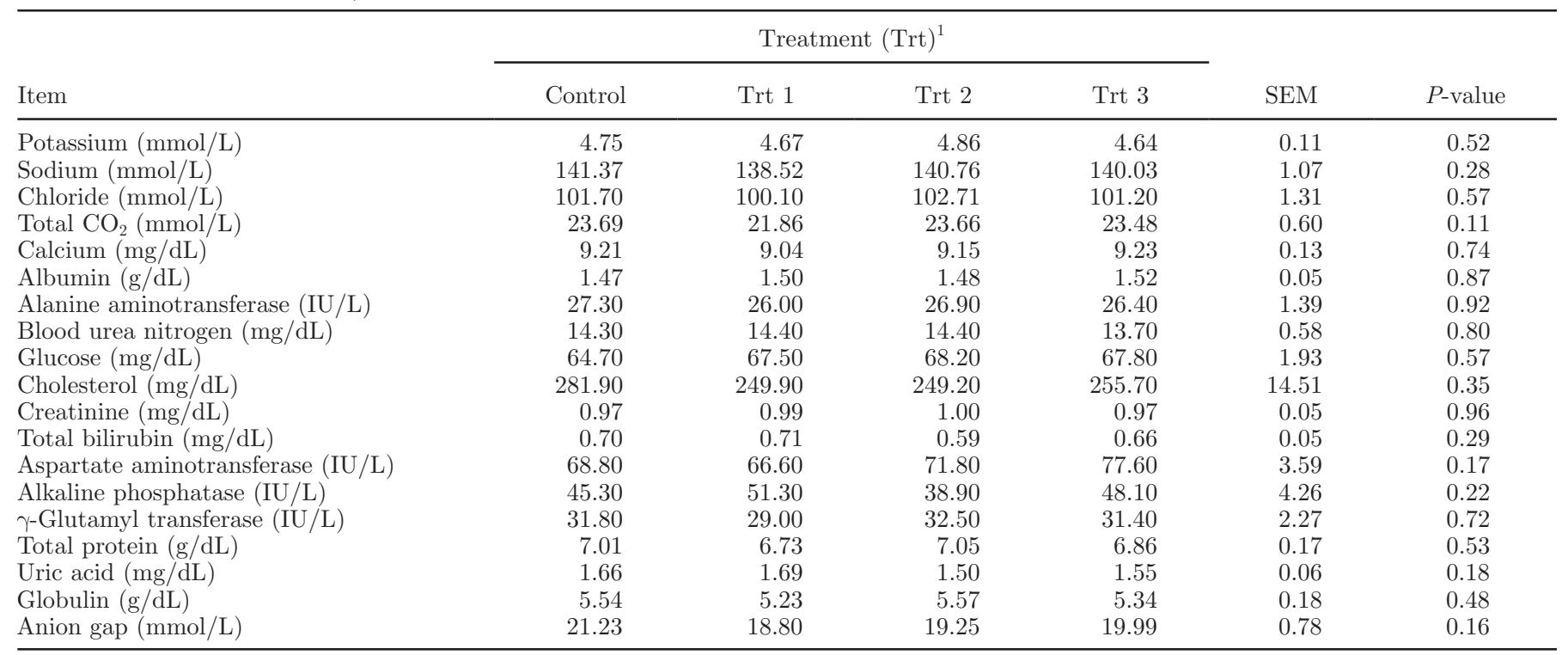

${ }^{1}$ Cows were administered melamine at $0,300,500$, and $1,000 \mathrm{mg} / \mathrm{d}$ per cow for control, Trt 1 , Trt 2 , and Trt 3, respectively.

that described by Battaglia et al. (2010); average daily milk production was $36.9 \pm 0.6 \mathrm{~kg}$ and $20.8 \pm 1.4 \mathrm{~kg}$ in the trial by Battaglia et al. (2010) and in the current study, respectively. To compare differences between milk melamine concentrations and melamine transfer efficiency reported in the present study with those reported by Shen et al. (2010), we entered our milk yield data into the equation of the Shen et al. (2010) paper

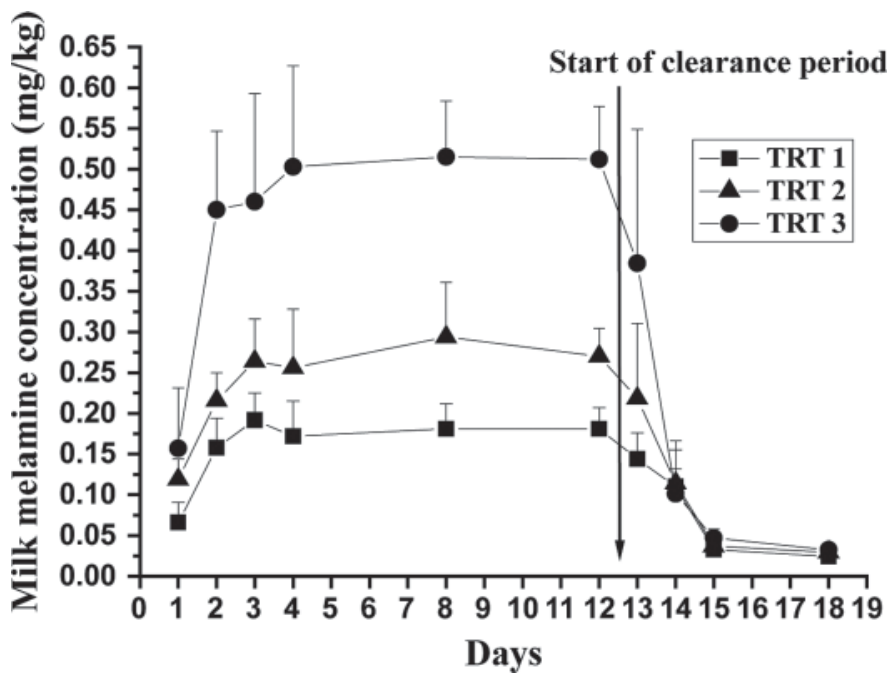

Figure 1. Melamine concentrations (mean \pm SD) in the milk of dairy cows fed 300 (Trt 1), 500 (Trt 2), or 1,000 (Trt 3) mg of melamine per day. For d 1, 2, 3, 4, 8, and 12, each value represents the mean of 10 cows. For d 13, 14, 15, and 18, each value of Trt 2 and Trt 3 represents the mean of 7 cows, and each value of Trt 1 represents the mean of 10 cows.
$[$ Transfer efficiency $(\%)=-0.18759+0.04734 \times$ milk yield $(\mathrm{kg})]$ to calculate the corresponding transfer efficiency. The milk yields of Trt 1 , Trt 2 , and Trt 3 were $22.22,21.00$, and $23.24 \mathrm{~kg}$, respectively, so the transfer efficiencies were $0.86,0.81$, and $0.91 \%$, respectively, which are close to the results obtained in the present study (Table 4). Different dairy cows fed various diets in different seasons caused the small differences observed in the 2 experiments. No significant treatment $\times$ block interaction was found for milk melamine concentration, melamine excretion via milk, or transfer efficiency.

The relationship between milk melamine concentration $(\mathrm{Y})$ and melamine intake $(\mathrm{X})$, under the experimental conditions of this study, can be expressed by the following equation:

$$
\begin{gathered}
\mathrm{Y}(\mathrm{mg} / \mathrm{kg})=0.00396+0.00047769 \mathrm{X}(\mathrm{mg} / \mathrm{d} \text { per cow }) ; \\
\mathrm{R}^{2}=0.90 ; F \text {-test: } P<0.0001 ; \\
\text { lack of fit test: } P=0.90 .
\end{gathered}
$$

The regression implies that milk melamine concentration increased linearly as melamine intake increased.

One of the important findings of the present study was that no cyanuric acid was detected in any of the milk samples from either the control or the 3 treatment groups after ingestion of different doses of melamine. Previous investigations have shown that some aerobic microorganisms, such as Arthrobacter spp., Klebsiella terragena, and Pseudomonas spp., possess the ability to hydrolyze melamine into cyanuric acid in vitro (Jutzi 
Table 4. Least squares means of concentration, yield, and transfer efficiency of melamine in milk of the experimental groups that received different doses of melamine (samples were collected at $\mathrm{d} 4,8$, and 12)

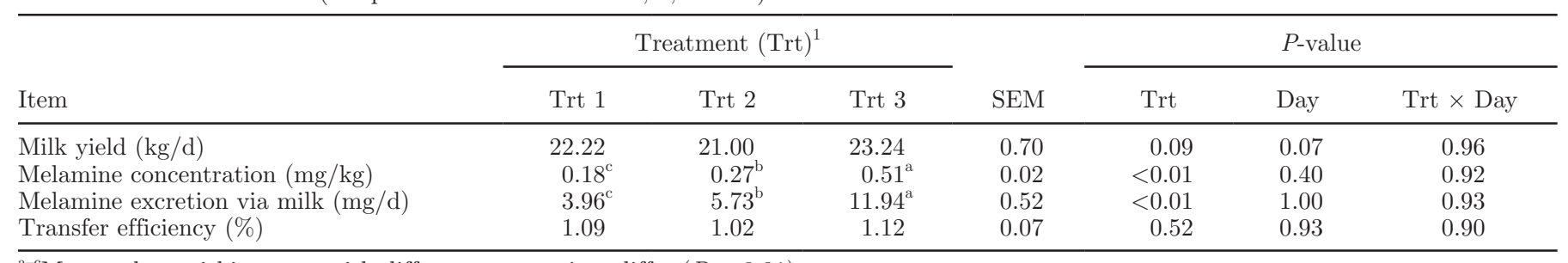

${ }^{a-c}$ Mean values within a row with different superscripts differ $(P<0.01)$.

${ }^{1}$ Cows were administered melamine at 300,500 , and $1,000 \mathrm{mg} / \mathrm{d}$ per cow for Trt 1 , Trt 2 , and Trt 3 , respectively.

et al., 1982; Shelton et al., 1997; Strong et al., 2002). Early in 1978, Newton and Utley (1978) demonstrated that although melamine was not an acceptable NPN source, it could be slowly hydrolyzed in the rumen. As Pseudomonas aeruginosa are found in the rumen of sheep (Duncan et al., 1999), it could be expected that melamine might be hydrolyzed into cyanuric acid and then absorbed by the rumen of dairy cows due to its lower acid dissociation constant ( $\mathrm{pKa}$; Battaglia et al., 2010). However, to our knowledge, no data are available concerning the vivo metabolism of melamine and cyanuric acid in the rumen.

\section{Melamine and Cyanuric Acid Residues in Plasma and Tissues}

To investigate the pathway of melamine and its analogs, such as cyanuric acid in the blood and tissues of dairy cows after ingesting melamine, concentrations of melamine and cyanuric acid were measured in plasma and tissues of dairy cows from Trt 2 and Trt 3. As shown in Figure 2, the amount of melamine residue in kidney, liver, mammary, bladder, gluteus medius, longissimus dorsi, and plasma was higher in dairy cows from Trt 3 than in those from Trt 2, indicating that the deposition of melamine was related to the ingested dose level. Lv et al. (2010) found a dose-dependent response of ingested melamine; that is, a higher dose of dietary melamine resulted in a higher level of melamine residue in tissues and serum. Chen et al. (2010) also demonstrated an apparent dose-response relationship between melamine ingestion and deposition in eggs. The kidney is considered the main excretion route for melamine, and melamine levels were found to be the highest in the kidney tissue samples $(0.5$ and $1.3 \mathrm{mg} / \mathrm{kg}$ in Trt 2 and Trt 3, respectively), which agrees with other published findings (Reimschuessel et al., 2008; Lv et al., 2010).

A novel finding of the present study was that when only melamine was fed to dairy cows, not only melamine but also cyanuric acid was detected in their tissues, which might indirectly indicate that melamine had been partly degraded in the body of dairy cows.
It has been reported that cyanuric acid, as one of the byproducts of hydrolyzed melamine, might be absorbed in the stomach of monogastric animals and excreted as an unmetabolized compound in the urine (Dobson et al., 2008; WHO, 2008). Simultaneously, the existence of other compounds associated with melamine degradation such as cyanuric acid might aggravate the toxicity
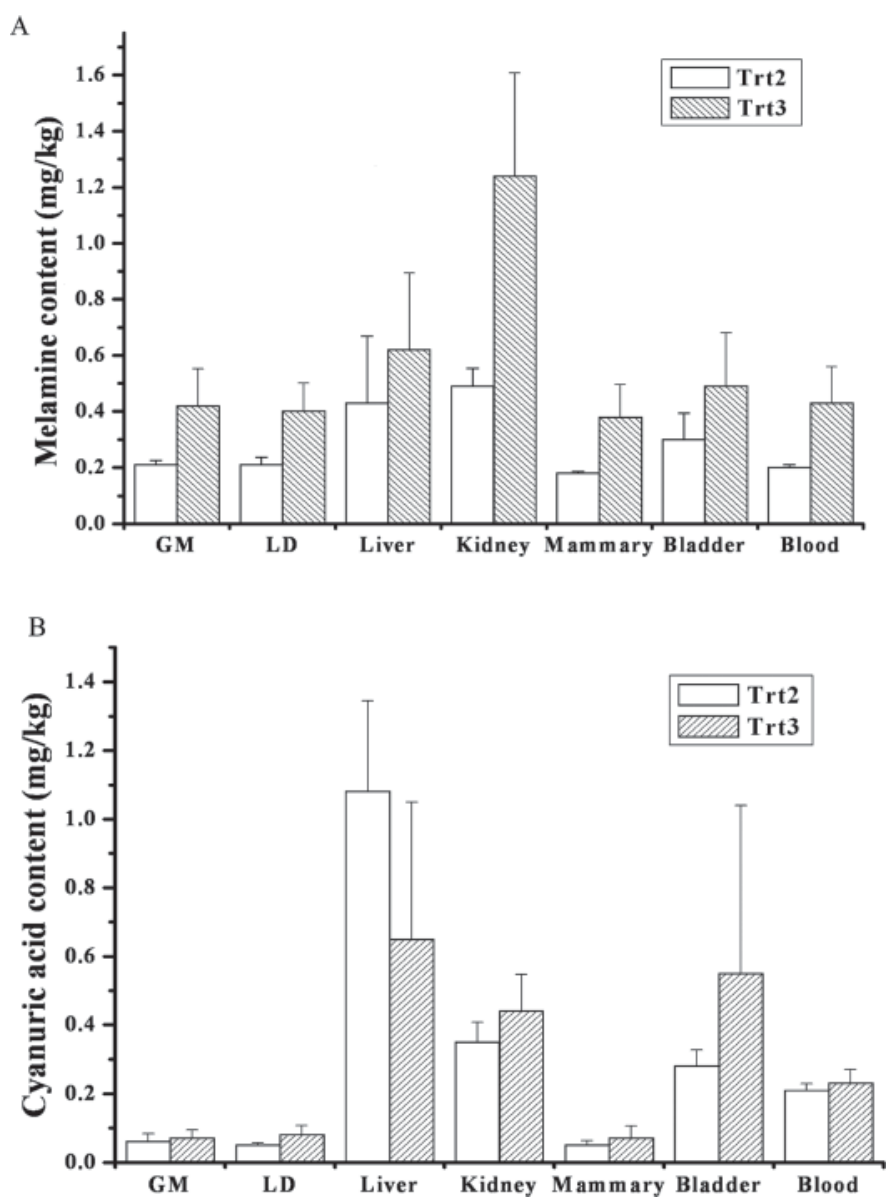

Figure 2. Melamine (A) or cyanuric acid (B) residues (mean \pm $\mathrm{SD}$ ) in gluteus medius (GM), longissimus dorsi (LD), liver, kidney, mammary, bladder, and blood. Each value represents the mean of 3 cows. Trt $=$ treatment. 
of melamine (Hau et al., 2009). Any of the triazines has low toxicity separately, but their combination, particularly that of melamine and cyanuric acid, may be more toxic by forming crystals that impair renal function (Brown et al., 2007; Puschner et al., 2007; Reimschuessel et al., 2008). In the present study, relatively higher levels of melamine and cyanuric acid were detected in liver, kidney, and bladder, which presented a serious health threat to the dairy cows. Results of the present study suggest that liver is another organ that might be affected by the ingestion of melamine and should be further studied.

\section{CONCLUSIONS}

Milk melamine concentration of the treated groups was significantly affected by the melamine dosing level, whereas transfer efficiency was not significantly affected. In the melamine-consuming groups, the milk melamine concentration increased quickly and was found to be similar at d 4, 8, and 12 after the first administration of melamine. Within $3 \mathrm{~d}$ after melamine administration was terminated ( $\mathrm{d} 15$ ), the melamine concentration in the milk decreased to $<0.05 \mathrm{mg} / \mathrm{kg}$, irrespective of melamine intake. Furthermore, melamine and cyanuric acid residues were found in most tissues when only melamine was fed to dairy cows, which might be the result of melamine being converted to cyanuric acid by microorganisms in the rumen. The melamine residue was about 2 -fold higher in the tissues of Trt 3 than in tissues of Trt 2, and the highest concentration was found in the kidney. In addition, liver, kidney, and bladder had higher cyanuric acid residues than the other analyzed tissues, indicating that liver might be another important organ that involves in the metabolism of cyanuric acid in dairy cows.

\section{ACKNOWLEDGMENTS}

This study was financially supported by an earmark fund for Melamine Limit in Feed from the Ministry of Agriculture and by an earmark fund for Modern AgroIndustry Technology Research System of the P. R. China (nycytx-04-01). We thank the staff of the State Key Laboratory of Animal Nutrition (Beijing, China) and the Milk and Dairy Inspection and Supervision Center of Ministry of Agriculture (Beijing, China) for technical assistance. We also acknowledge the contributions made by the personnel of the Beijing Cangdafu Dairy Farm in support of this research.

\section{REFERENCES}

Battaglia, M., C. W. Cruywagen, T. Bertuzzi, A. Gallo, M. Moschini, G. Piva, and F. Masoero. 2010. Transfer of melamine from feed to milk and from milk to cheese and whey in lactating dairy cows fed single oral doses. J. Dairy Sci. 93:5338-5347.

Baynes, R. E., G. Smith, S. E. Mason, E. Barrett, B. M. Barlow, and J. E. Riviere. 2008. Pharmacokinetics of melamine in pigs following intravenous administration. Food Chem. Toxicol. 46:1196-1200.

Brown, C. A., K. S. Jeong, R. H. Poppenga, B. Puschner, D. M. Miller, A. E. Ellis, K. I. Kang, S. Sum, A. M. Cistola, and S. A. Brown. 2007. Outbreaks of renal failure associated with melamine and cyanuric acid in dogs and cats in 2004 and 2007. J. Vet. Diagn. Invest. 19:525-531.

Chen, Y., W. Yang, Z. Wang, Y. Peng, B. Li, L. Zhang, and L. Gong. 2010. Deposition of melamine in eggs from laying hens exposed to melamine contaminated feed. J. Agric. Food Chem. 58:3512-3516.

China NY/t 34. 2004. Feeding Standard of Dairy Cattle. China NongYe HangYe Biaozhun/Tuijian-34. China Agricultural Publisher, Beijing, China.

Clark, R. 1966. Melamine crystalluria in sheep. J. S. Afr. Vet. Med. Assoc. 37:349-351.

Cruywagen, C. W., M. A. Stander, M. Adonis, and T. Calitz. 2009. Hot topic: Pathway confirmed for the transmission of melamine from feed to cow's milk. J. Dairy Sci. 92:2046-2050.

Dobson, R. L. M., S. Motlagh, M. Quijano, R. T. Cambron, T. R. Baker, A. M. Pullen, B. T. Regg, A. S. Bigalow-Kern, T. Vennard, A. Fix, R. Reimschuessel, G. Overmann, Y. Shan, and G. P. Daston. 2008. Identification and characterization of toxicity of contaminants in pet food leading to an outbreak of renal toxicity in cats and dogs. Toxicol. Sci. 106:251-262.

Duncan, S. H., C. J. Doherty, J. R. W. Govan, S. Neogrady, P. Galfi, and C. S. Stewart. 1999. Characteristics of sheep-rumen isolates of Pseudomonas aeruginosa inhibitory to the growth of Escherichia coli O157. FEMS Microbiol. Lett. 180:305-310.

EFSA. 2008. Statement of EFSA on risks for public health duo to the presences of melamine in infant milk and other milk products in China. EFSA J. 807:1-10.

FDA. 2008a. Interim Safety and Risk Assessment of Melamine and its Analogues in Food for Humans. Accessed May 5, 2009. http:// www.fda.gov/OHRMS/DOCKETS/98fr/FDA-2008-N-0574-bkg. pdf.

FDA. 2008b. Update: Interim Safety and Risk Assessment of Melamine and its Analogues in Food for Humans. Accessed Dec. 28, 2008. http://www.fda.gov/Food/FoodSafety/FoodContaminants Adulteration/ChemicalContaminants/Melamine/ucm164520.htm.

FDA. 2007. Interim Melamine and Analogues Safety /Risk Assessment. Accessed Feb. 10, 2009. http://www.fda.gov/Food/Food Safety/FoodContaminantsAdulteration/ChemicalContaminants/ Melamine/ucm164658.htm.

Filigenzi, M. S., B. Puschner, L. S. Aston, and R. H. Poppenga. 2008. Diagnostic determination of melamine and related compounds in kidney tissue by liquid chromatography/tandem mass spectrometry. J. Agric. Food Chem. 56:7593-7599.

Hau, A. K., T. H. Kwan, and P. K. Li. 2009. Melamine toxicity and the kidney. J. Am. Soc. Nephrol. 20:245-250.

Jutzi, K., A. M. Cook, and R. Hütter. 1982. The degradative pathway of the s-triazine melamine. Biochem. J. 208:679-684.

Lam, C. W., L. Lan, X. Che, S. Tam, S. S. Y. Wong, Y. Chen, J. Jin, S. H. Tao, X. M. Tang, K. Y. Yuen, and P. K. H. Tam. 2009. Diagnosis and spectrum of melamine-related renal disease: Plausible mechanism of stone formation in humans. Clin. Chim. Acta 402:150-155.

Lv, X., J. Wang, L. Wu, J. Qiu, J. Li, Z. Wu, and Y. Qin. 2010. Tissue deposition and residue depletion in lambs exposed to melamine and cyanuric acid-contaminated diets. J. Agric. Food Chem. 58:943-948.

Mast, R. W., A. R. Jeffcoat, B. M. Sadler, R. C. Kraska, and M. A. Friedman. 1983. Metabolism, disposition and excretion of $\left[{ }^{14} \mathrm{C}\right]$ melamine in male Fischer 344 rats. Food Chem. Toxicol. 21:807810.

Newton, G. L., and P. R. Utley. 1978. Melamine as a dietary nitrogen source for ruminants. J. Anim. Sci. 47:1338-1344.

Ogasawara, H., K. Imaida, H. Ishiwata, K. Toyoda, T. Kawanishi, C. Uneyama, S. Hayashi, M. Takahashi, and Y. Hayashi. 1995. 
Urinary bladder carcinogenesis induced by melamine in F344 male rats: Correlation between carcinogenicity and urolith formation. Carcinogenesis 16:2773-2777.

Puschner, B., R. H. Poppenga, L. J. Lownsteirn, M. S. Filigenzi, and P. A. Pesavento. 2007. Assessment of melamine and cyanuric acid toxicity in cats. J. Vet. Diagn. Invest. 19:616-624.

Reimschuessel, R., C. M. Gieseker, R. A. Miller, J. Ward, J. Boehmer, N. Rummel, D. N. Heller, C. Nochetto, G. K. Hemakanthi de Alwis, N. Bataller, W. C. Andersen, S. B. Turnipseed, C. M. Karbiwnyk, R. Duane Satzger, J. B. Crowe, N. R. Wilber, M. K. Reinhard, J. F. Roberts, and M. R. Witkowski. 2008. Evaluation of the renal effects of experimental feeding of melamine and cyanuric acid to fish and pigs. Am. J. Vet. Res. 69:1217-1228.

Shelton, D. R., J. S. Karns, G. W. McCarty, and D. R. Durham. 1997. Metabolism of melamine by Klebsiella terragena. Appl. Environ. Microbiol. 63:2832-2835.

Shen, J. S., J. Q. Wang, H. Y. Wei, D. P. Bu, P. Sun, and L. Y. Zhou. 2010. Transfer efficiency of melamine from feed to milk in lactating dairy cows fed with different doses of melamine. J. Dairy Sci. 93:2060-2066.
Strong, L. C., C. Rosendahl, G. Johnson, M. J. Sadowsky, and L. P. Wackett. 2002. Arthrobacter aurescens TC1 metabolizes diverse striazine ring compounds. Appl. Environ. Microbiol. 68:5973-5980.

Subrayan, R. P., and P. G. Rasmussen. 1995. An overview of materials composed of carbon and nitrogen. Trends Polym. Sci. (Regul. Ed.) $3: 165-172$.

Weil, E. D., and V. Choudhary. 1995. Flame-retarding plastics and elastomers with melamine. J. Fire Sci. 13:104-126.

WHO. 2008. Melamine and cyanotic acid: Toxicity, preliminary risk assessment and guidance on levels in food. Accessed Feb. 10, 2010 http://www.who.int/mediacentre/news/releases/2008/pr48/en/ index.html.

Wu, Y. T., C. M. Huang, C. C. Lin, W. A. Ho, L. C. Lin, T. F. Chiu, D. C. Tarng, C. H. Lin, and T. H. Tsai. 2009. Determination of melamine in rat plasma, liver, kidney, spleen, bladder and brain by liquid chromatography-tandem mass spectrometry. J. Chromatogr. A 1216:7595-7601. 